\title{
TEKNOLOGI PENGOLAHAN SAMPAH DAN AIR LIMBAH
}

\author{
Oleh : Arie Herlambang dan Djoko Heru Martono \\ Pusat Teknologi Lingkungan, TPSA - BPPT
}

\begin{abstract}
Solid waste has become a problem for large and small cities, as they relate to environmental sanitation and health, as well as aesthetic issues. High intensity of rainfall influence in a high solubility results of decomposition of waste in both TPS and TPA, brought the flow of water and water soak to soil or water flow to the public drainage. Law Number 8 Year 2007 on waste management require sanitary landfill technology. Currently most of the TPA are still not meet the full construction of sanitary landfill and need to be supported by the application of the $3 R$ (Reduced, Reused, Recycle) program in solidwaste. Processing waste liquid derived from the leachate (seepage water) waste requiring special treatment. There are many type of waste water technology processing, the most important, It can be applied and product water quality meet the standard quality.
\end{abstract}

Keywords : Sampah, 3 R, Tempat Pembuagan Akhir (TPA), Leachate Treatment.

\section{PENDAHULUAN}

Masalah lingkungan merupakan issue global yang berdampak terhadap banyak aspek kehidupan. Namun pemahaman tentang lingkungan dan khususnya limbah, nampaknya masih dalam tahap gaya hidup dan belum merupakan pola berpikir bagi masyarakat pada umumnya. Sampah adalah salah satu jenis limbah yang mau tidak mau dan sadar tidak sadar merupakan bagian dari kehidupan kita. Dimanapun kita bergerak maka akan meninggalkan bekas yang disebut limbah termasuk sampah. Sistem pengelolaan sampah dapat didekati dengan prinsip $3 \mathrm{R}$ yang diambil dari istilah asing yaitu Reduce, Reuse, dan Recycle sesuai hirarki.

Saat ini, pengelolaan sampah terutama dari perkotaan, masih menggunakan paradigma lama yaitu kumpul, angkut, dan buang. Pengelolaan seperti ini telah terbukti menyebabkan banyak sekali masalah lingkungan mulai dari banjir akibat sungai tersumbat, cairan pekat berbahaya dari tumpukan sampah yang masuk ke dalam sumber air minum masyarakat, sampai pada longsornya TPA (tempat pembuangan akhir sampah) yang mengakibatkan ratusan jiwa melayang.

Prinsip $3 \mathrm{R}$ merupakan prinsip yang sudah diakui keberhasilannya oleh negara-negara maju dalam mengelola limbahnya, sedang di Indonesia, prinsip tersebut masih bersifat wacana. Dalam menerapkan prinsip 3R dalam sistem pengelolaan sampah diperlukan dukungan teknologi yang memadai. Dukungan tersebut sangat diperlukan dalam upaya mencari metoda dan cara yang sesuai dengan kondisi Indonesia. Sampah dari perkotaan mayoritas $(70-80 \%)$ terdiri dari bahan organik yang dapat terurai secara alamiah dan $20-30 \%$ bahan non organik yang meliputi plastik, logam, gelas, dan lain-lain.

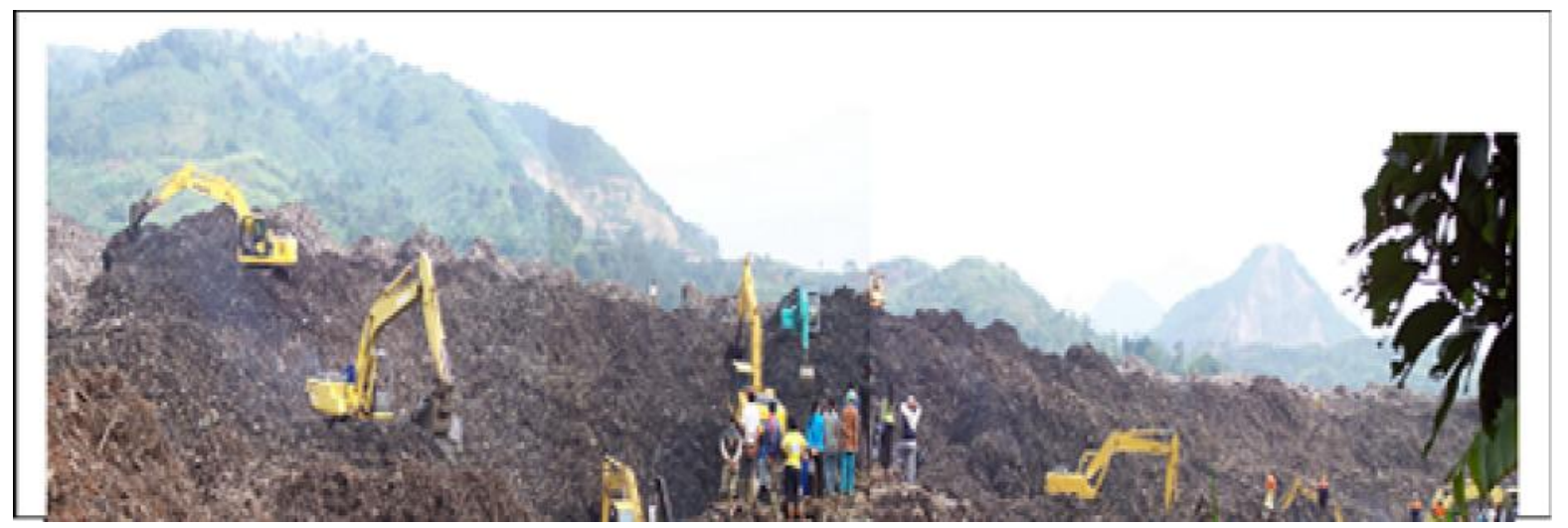

Gambar 1. TPA Yang Semakin Sulit Lahannya 
Bersamaan dengan permasalahan sampah, masalah air limbah di Indonesia baik limbah domestik maupun limbah industri sampai saat ini masih menjadi masalah yang serius. Di dalam proses pengolahan air limbah, khususnya yang mengandung pencemar senyawa organik, teknologi yang digunakan sebagian besar menggunakan aktifitas mikro-organisme untuk menguraikan senyawa pencemar organik tersebut. Proses pemgolahan air limbah dengan aktifitas mikro-organisme biasa disebut dengan proses biologis. Proses pengolahan air limbah secara biologis tersebut dapat dilakukan pada kondisi aerobik (dengan udara), kondisi anaerobik (tanpa udara) atau kombinasi anaerobik dan aerobik. Proses biologis aerobik biasanya digunakan untuk pengolahan air limbah dengan beban BOD yang tidak terlalu besar, sedangkan proses biologis anaerobik digunakan untuk pengolahan air limbah dengan beban BOD yang sangat tinggi.

Namun demikian tidak semua limbah cair dapat dilakukan sepenuhnya dengan cara biologis. Beberapa limbah organik yang sulit terurai membutukan kombinasi proses antara proses kimia dan biologis, seperti misalnya penghilangan warna pada limbah tekstil atau pengolahan limbah kosmetik yang banyak mengandung alkohol. Pada kondisi limbah yang demikian, dilakukan terlebih dahulu proses kimia untuk proses koagulasi dan flokulasi atau penyederhanaan bentuk ikatan atau penghilangan unsur-unsur yang bersifat toksik untuk kehidupan biologi (bakteri pengurai limbah).

Pengolahan air limbah secara biologis umumnya dapat dibagi menjadi tiga, yakni : proses biologis dengan biakan tersuspensi (suspended culture), proses biologis dengan biakan melekat (attached culture) dan proses pengolahan dengan sistem lagoon atau kolam. Proses biologis dengan biakan tersuspensi adalah sistem pengolahan dengan menggunakan aktifitas mikroorganisme untuk menguraikan senyawa pencemar yang ada dalam air dan mikroorganime yang digunakan dibiakkan secara tersuspensi di dalam suatu reaktor. Beberapa contoh proses pengolahan dengan sistem ini, antara lain : proses lumpur aktif standar/konvesional (standard activated sludge), step aeration, contact stabilization, extended aeration, oxidation ditch (kolam oksidasi sistem parit) dan lainnya. Proses biologis dengan biakan melekat yakni proses pengolahan limbah dimana mikroorganisme yang digunakan dibiakkan pada suatu media, sehingga mikroorganisme tersebut melekat pada permukaan media. Proses ini disebut juga dengan proses film mikrobiologis atau proses biofilm.

Beberapa contoh teknologi pengolahan air limbah dengan cara ini antara lain : trickling filter, biofilter tercelup, reaktor kontak biologis putar (rotating biological contactor/RBC), contact aeration/oxidation (aerasi kontak) dan lainnya. Proses pengolahan air limbah secara biologis dengan lagoon atau kolam adalah dengan menampung air limbah pada suatu kolam yang luas dengan waktu tinggal yang cukup lama, sehingga dengan aktifitas mikroorganisme yang tumbuh secara alami, senyawa pencemar yang ada dalam air akan terurai. Untuk mempercepat proses penguraian senyawa pencemar atau memperpendek waktu tinggal dapat juga dilakukan proses aerasi. Salah satu contoh proses pengolahan air limbah dengan cara ini adalah kolam aerasi atau kolam stabilisasi (stabilization pond). Proses dengan sistem lagoon tersebut kadang-kadang dikategorikan sebagai proses biologis dengan biakan tersuspensi.

\section{MINIMISASI SAMPAH MELALUI PROGRAM 3 R (REDUCE, REUSED, RECYCLE)}

Reduce merupakan prinsip pengelolaan sampah pada hirarki yang paling tinggi. Dengan menerapkan prinsip reduce, maka diharapkan tidak akan terjadi produksi sampah sebanyak sekarang ini. Dalam menerapkan prinsip reduce peran teknologi sangat dominan, yaitu dalam mencari dan menciptakan produk yang lebih ramah lingkungan yang minim sisa yang akan tidak digunakan. Produk ramah lingkungan merupakan produk yang tidak menyisakan sampah atau mencegah terjadinya sampah. Produk ramah lingkungan dapat berupa :

(1) produk yang dapat terurai secara alamiah,

(2) produk yang berumur panjang sehingga tidak cepat menjadi sampah,

(3) produk yang dapat didaur ulang,

(4) produk yang dapat digunakan untuk hal lain misalnya bahan bakar; dan

(5) produk yang dalam pembuatannya tidak menciptakan banyak limbah.

Dalam tingkatan masyarakat sebagai pengguna produk, maka upaya pencegahan sampah dapat dilakukan dengan tidak memilih produk yang tidak ramah lingkungan.

Reused merupakan usaha dalam mencegah terjadinya sampah dengan cara menggunakan kembali satu jenis produk secara berulang. Prinsip Reused telah diterapkan oleh 
beberapa produsen seperti dengan prinsip isi ulang (refill). Reused merupakan sistem pencegahan terjadinya sampah dalam tingkat masyarakat. Menggunakan barang yang sudah tidak sesuai fungsinya untuk fungsi yang lain merupakan cara memperpanjang umur produk dan mencegahnya menjadi sampah.

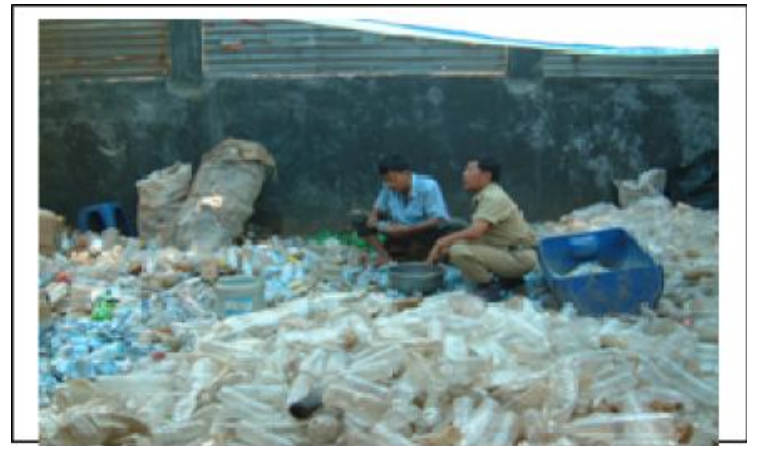

Gambar 2. Proses Daur Ulang Produk Limbah Plastik

Recycle merupakan hirarki terendah dalam upaya mengurangi sampah. Recycle banyak dilakukan pada posisi "pipe-end" dari barang produk atau dengan kata lain dilakukan setelah produk menjadi sampah. Limbah dari satu kegiatan baik itu industri maupun perorangan belum tentu merupakan "limbah" bagi kegiatan atau orang lain. Sebagai contoh barang yang kita anggap sudah menjadi sampah dan kita buang masih merupakan barang berharga bagi orang lain, yaitu pemulung.

Dari penelitian-penelitian yang dilakukan oleh P3TL-BPPT, hampir $60 \%$ dari sampah non organik dapat terserap kembali sebagai bahan baku sekunder bagi berbagai produk. Sampah logam hampir tidak pernah ditemukan di lokasi pembuangan akhir, plastik yang tersisa di TPA hanya dari jenis plastik lembaran untuk bahan pembungkus, dll. Untuk sampah yang dapat terurai, penelitian yang dilakukan oleh P3TLBPPT memperoleh hasil bahwa bahan organik dapat terurai lebih cepat di Indonesia, yaitu dalam waktu 6 minggu dibanding di negara yang mempunyai iklim subtropis. Teknologi penguraian (pengkomposan) yang dikaji dan dikembangkan adalah teknologi pengkomposan "open windrows". Beberapa instalasi uji coba baik dalam skala kecil 2 ton - 10 ton limbah per hari, maupun skala menengah 30 ton limbah per hari menunjukkan hasil yang baik dalam mengubah bahan organik menjadi media seperti humus yang dapat memperbaiki struktur tanah yang sudah kritis.

Pada penelitian sistem pengolahan
sampah terpadu untuk perkotaan, yang menerapkan kombinasi teknologi pengkomposan dan daur ulang, maka antara 50 - $70 \%$ sampah perkotaan dapat diolah, sehingga sisa yang harus dibuang atau ditimbun di TPA hanya sekitar 30 - $50 \%$ dari jumlah yang diproduksi. Pengolahan sampah lebih mendekat pada sumbernya, bukan saja lahan TPA yang dapat dihemat, akan tetapi biaya angkut sampah juga dapat dihemat.

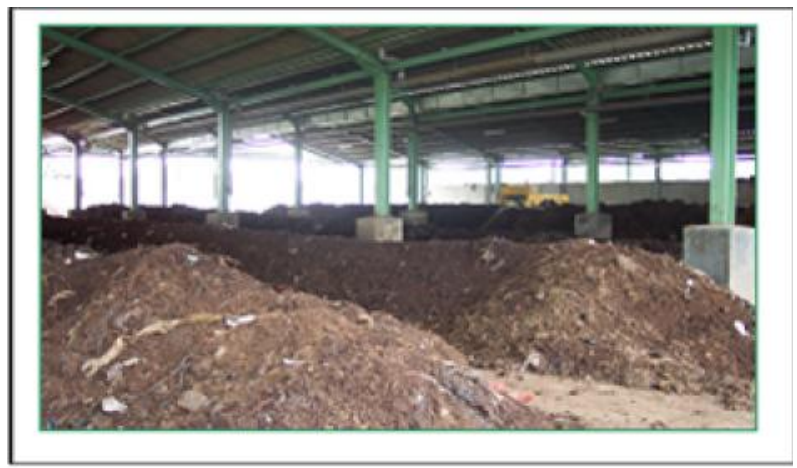

Gambar 3. Produksi Kompos di Rumah

Pemotongan Hewan Cakung, Jakarta.

Selain pengkajian dan penerapan teknologi dalam pengelolaan sampah, maka dari pengalaman penelitian selama ini, ada beberapa aspek yang sangat berpengaruh dalam penerapan apapun jenis teknologi yang akan digunakan. Setidaknya ada empat aspek lain yang secara simultan harus juga dilakukan, yaitu:

\section{(1) Aspek peran serta stakeholder}

Keterlibatan dari seluruh stakeholder sangat mempengaruhi keberhasilan dari teknologi yang diterapkan. Salah satu contoh adalah peran serta dalam memilah sampah organik dan non organik sangat mempengaruhi teknologi yang akan digunakan. Proses pemilahan sampah dalam jumlah besar di instalasi pengolahan sampah memerlukan teknologi yang cukup mahal dan sumber daya manusia untuk pemilahan manual.

\section{(2) Aspek kelembagaan dan institusi}

Sampah merupakan bahan yang cukup sensitif keberadaannya, karena jika tidak dikelola dengan baik dapat menyebabkan kerusakan lingkungan yang pada akhirnya mengganggu tingkat kesehatan masyarakat. Oleh karena itu, maka adanya kewenangan dan kewajiban yang jelas pada setiap institusi yang terlibat sangat diperlukan. Institusi pengelola, pengawasan, pendanaan, harus bersama-sama secara sinergi melakukan sistem pengelolaan limbah. Hampir semua kota besar, pengelolaan maupun pengawasan sistem pengelolaan sampah 
dilaksanakan oleh satu Dinas baik itu Dinas kebersihan atau Dinas Kebersihan dan Pertamanan, dsb., akan memberikan beban yang sangat berat bagi dinas yang bersangkutan karena masalah sampah adalah multisektoral.

\section{(3) Aspek pendanaan.}

Aspek pendanaan merupakan aspek yang sampai detik ini merupakan masalah besar bagi negara ini dan juga kota-kota di Indonesia dalam sistem pengelolaan sampah. Tidak dapat dipungkiri bahwa mengelola sampah dari mulai pengumpulan, pengangkutan, pengolahan, dan pembuangan akhir, merupakan cost center. Hal ini harus disadari oleh seluruh stakeholder yang terlibat termasuk masyarakat. Dana yang kurang memadai dalam mengelola sampah seperti saat ini telah terbukti menimbulkan masalah baik pada lingkungan maupun pada kesehatan masyarakat. Banjir akibat tersumbatnya sungai oleh sampah merupakan salah satu dari tidak cukupnya alat transportasi sampah, sehingga banyak sampah yang tidak terangkut, walaupun ada juga akibat kurangnya kesadaran dari masyarakat. Banyak kota besar yang jumlah kendaraan angkut sampahnya tidak sesuai dibandingkan jumlah sampah yang harus dikelola.

\section{(4) Aspek hukum atau pengaturan.}

Tanpa payung hukum yang jelas dalam melaksanakan sistem pengelolaan sampah yang baik, maka masalah pencemaran akibat sampah akan tetap seperti saat ini.

Dari uraian diatas, apapun bentuk teknologi pengelolaan sampah yang telah dikuasai, akan tetap sulit untuk diterapkan, jika aspek lain tidak mendukung. Bisnis dalam daur ulang sampah non organik sudah terlihat nyata di masyarakat dapat berjalan dengan baik dan menjanjikan, walaupun masih dalam sektor informal. Kompos yang merupakan hasil olahan sampah organik yang sampai saat ini masih belum banyak dilirik pelaku bisnis.

Kecenderungan masyarakat tertentu menghindari bahan kimia dalam sayuran menciptakan masyarakat pencinta sayuran organik. Dengan berkembangnya trend ini, maka kompos sebagai media tanam yang baik mempunyai peluang pasar yang besar. Jika pasar sudah terbentuk dengan baik, maka pengolahan sampah bukan saja untuk menciptakan lingkungan yang lebih bersih dan sehat, akan tetapi juga menghasilkan produk sampingan yang dapat menciptakan revenue bagi pengoperasian instalasi pengolahan.

\section{TEKNOLOGI PENGOLAHAN LIMBAH CAIR}

\subsection{Teknologi Pengolahan Limbah Umum}

Secara garis besar klasifikasi proses pengolahan air limbah secara biologis dapat dilihat seperti pada Gambar 4, yaitu Pengolahan Limbah dengan Proses Biomassa Tersuspensi (Suspended Culture), Proses Biomassa Melekat (Attached Culture), dan Proses dengan sistem lagoon. Pemilihan teknologi pengolahan limbah tergantung pada jenis limbah yang akan diolah, ketersediaan lahan, biaya investasi, biaya operasional, kemudahan dalam pemeliharaan, dan kualitas hasil olahan yang dipersyaratkan. Peran bakteri pengurai dalam pengolahan limbah sistem biologi ini sangat dominan, oleh karena itu pemahaman proses mikrobiologis sangat diperlukan dalam pemilihan teknologi pengolahan air limbah.

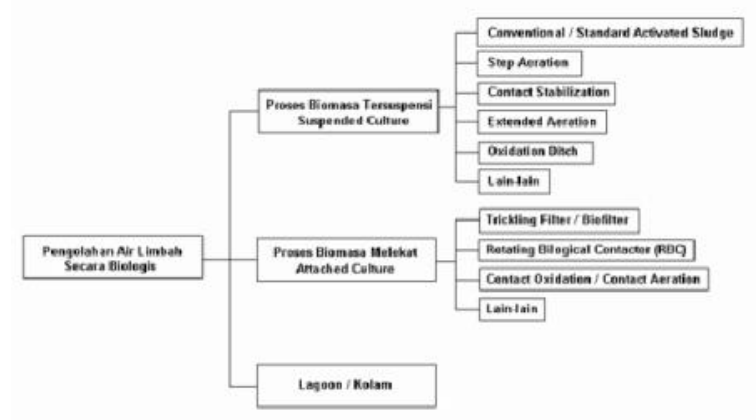

Gambar 4. Klasifikasi Proses Pengolahan Air Limbah Secara Biologis

\subsection{Pengolahan Air Limbah Dengan Proses Mikrobiologis}

\section{(1). Klasifikasi Proses Mikrobiologis}

Proses pengolahan air limbah dengan sistem biologi dikenal juga dengan proses mikrobiologi yang berhubungan erat dengan pembentukan biofilm atau biofilter. Secara garis besar dapat diklasifikasikan seperti pada Gambar 5. Proses tersebut dapat dilakukan dalam kondisi aerobik, anaerobik atau kombinasi keduanya (anaerobik dan aerobik). Proses aerobik dilakukan dengan kondisi adanya oksigen terlarut di dalam reaktor air limbah, dan proses anaerobik dilakukan dengan tanpa adanya oksigen dalam reaktor air limbah. Sedangkan proses kombinasi anaerob-aerob adalah gabungan proses anaerobik dan proses aerobik. Proses ini biasanya digunakan untuk menghilangkan kandungan nitrogen di dalam air limbah.

Pada kondisi aerobik terjadi proses nitrifikasi, yakni nitrogen ammonium diubah menjadi nitrat $\left(\mathrm{NH}_{4}{ }^{+} \rightarrow \mathrm{NO}_{3}\right)$ dan pada kondisi 
anaerobik terjadi proses denitrifikasi, yakni nitrat yang terbentuk diubah menjadi gas nitrogen $\left(\mathrm{NO}_{3}\right.$ $\rightarrow \mathrm{N}_{2}$ ).

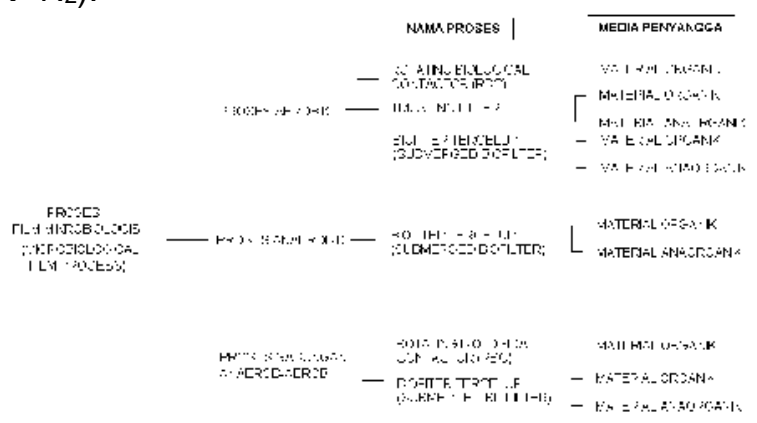

Gambar 5. Klasifikasi Cara Pengolahan Air Limbah Dengan Proses Film Mikrobiologis

\section{(2). Prinsip Pengolahan Limbah Dengan Biofilm}

Mekanisme proses metabolisme di dalam sistem biofilm aerobik secara sederhana dapat diterangkan seperti pada Gambar 6. Gambar tersebut menunjukkan suatu sistem biofilm yang terdiri dari medium penyangga, lapisan biofilm yang melekat pada medium, lapisan alir limbah dan lapisan udara yang terletak diluar. Senyawa pencemar yang ada di dalam air limbah, misalnya senyawa organik (BOD, COD), ammonia, phospor dan lainnya akan terdifusi ke dalam lapisan atau film biologis yang melekat pada permukaan medium. Pada saat yang bersamaan dengan menggunakan oksigen yang terlarut di dalam air limbah senyawa pencemar tersebut akan diuraikan oleh mikroorganisme yang ada di dalam lapisan biofilm dan energi yang dihasilhan akan diubah menjadi biomasa.

Pemberian oksigen pada lapisan biofilm dapat dilakukan dengan beberapa cara, misalnya pada sistem RBC, yakni dengan cara kontak dengan udara luar. Pada sistem "Trickling Filter" dengan aliran balik udara, sedangkan pada sistem biofilter tercelup dengan menggunakan blower udara atau pompa sirkulasi. Jika lapisan mikrobiologis cukup tebal, maka pada bagian luar lapisan mikrobiologis akan berada dalam kondisi aerobik, sedangkan pada bagian dalam biofilm yang melekat pada medium akan berada dalam kondisi anaerobik.

Pada kondisi anaerobik akan terbentuk gas $\mathrm{H}_{2} \mathrm{~S}$, dan jika konsentrasi oksigen terlarut cukup besar, maka gas $\mathrm{H}_{2} \mathrm{~S}$ yang terbentuk tersebut akan diubah menjadi sulfat $\left(\mathrm{SO}_{4}\right)$ oleh bakteri sulfat yang ada di dalam biofilm. Selain itu pada zona aerobik nitrogen-ammonium akan diubah menjadi nitrit dan nitrat dan selanjutnya pada zona anaerobik nitrat yang terbentuk mengalami proses denitrifikasi menjadi gas nitrogen. Oleh karena di dalam sistem bioflim terjadi kondisi anaerobik dan aerobik pada saat yang bersamaan, maka dengan sistem tersebut, proses penghilangan senyawa nitrogen menjadi lebih mudah dan penguraian limbah menjadi lebih sempurna dan tidak menghasilkan lumpur limbah dalam jumlah yang besar (Gambar 7).

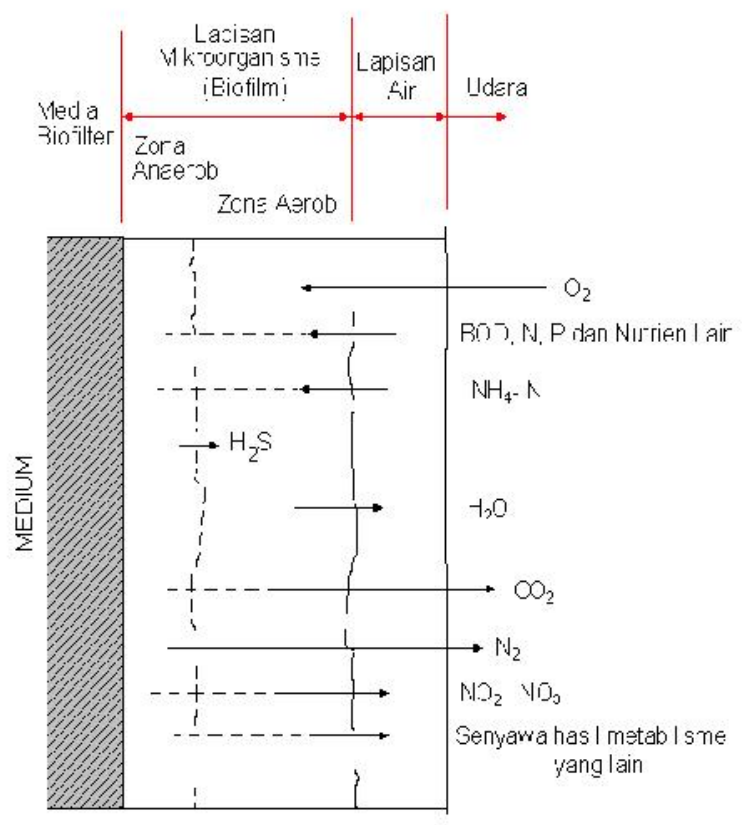

Gambar 6. Mekanisme Proses Metabolisme di Dalam Sistem Biofilm

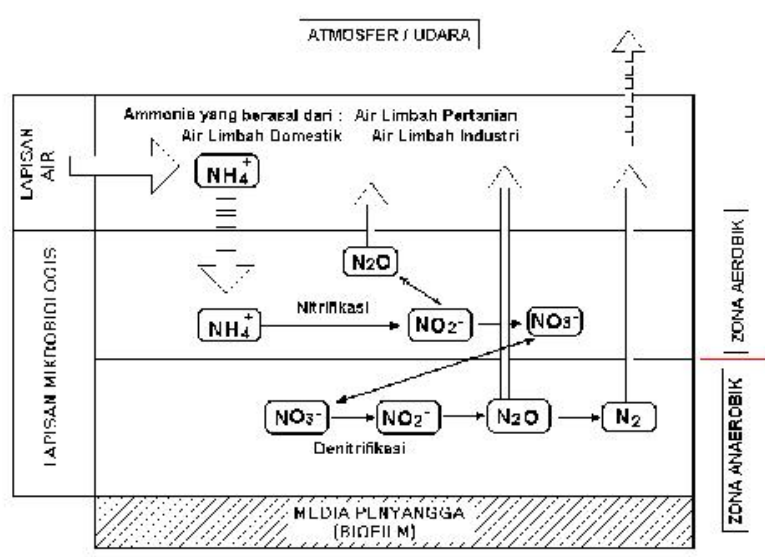

Gambar 7. Mekanisne Penghilangan Ammonia di Dalam Proses Biofilter

(3). Keunggulan Proses Mikrobiologis

Pengolahan air limbah dengan proses biofim mempunyai beberapa keunggulan antara lain :

a. Pengoperasiannya mudah. Di dalam proses pengolahan air limbah dengan sistem biofilm, tanpa dilakukan sirkulasi lumpur, tidak terjadi masalah "bulking" seperti pada proses 
lumpur aktif (Activated sludge process). Oleh karena itu pengelolaannya sangat mudah.

b. Lumpur yang dihasilkan sedikit. Dibandingkan dengan proses lumpur aktif, lumpur yang dihasilkan pada proses biofilm relatif lebih kecil. Di dalam proses lumpur aktif antara $30-60 \%$ dari BOD yang dihilangkan (removal BOD) diubah menjadi lumpur aktif (biomasa), sedangkan pada proses biofilm hanya sekitar $10-30 \%$. Hal ini disebabkan karena pada proses biofilm rantai makanan lebih panjang dan melibatkan aktifitas mikroorganisme dengan orde yang lebih tinggi dibandingkan pada proses lumpur aktif.

c. Dapat digunakan untuk pengolahan air limbah dengan konsentrasi rendah maupun konsentrasi tinggi. Pengolahan air limbah dengan sistem biofilm mikroorganisme atau mikroba melekat pada permukaan medium penyangga, maka pengontrolan terhadap mikroorganisme atau mikroba lebih mudah.

d. Tahan terhadap fluktuasi jumlah air limbah maupun fluktuasi konsentrasi. Naik turunnya debit dan konsentrasi limbah tidak berpengaruh terhadap kualitas hasil olahan, karena populasi bakteri relatif stabil dan melekat pada media biofilter.

e. Pengaruh penurunan suhu terhadap efisiensi pengolahan kecil. jika suhu air limbah turun, maka aktifitas mikroorganisme juga berkurang, tetapi karena di dalam proses biofilm substrat maupun enzim dapat terdifusi sampai ke bagian dalam lapisan biofilm dan juga lapisan biofilm bertambah tebal, maka pengaruh penurunan suhu tidak begitu besar.

\section{(4). Pengolahan Limbah Dengan Proses Biofilm}

Proses pengolahan air limbah dengan proses biofilm atau biofilter tercelup dilakukan dengan cara mengalirkan air limbah ke dalam reaktor biologis yang di dalamnya diisi dengan media penyangga untuk pengembang-biakan mikroorganisme dengan atau tanpa aerasi. Untuk proses anaerobik dilakukan tanpa pemberian udara atau oksigen. Posisi media biofilter tercelup di bawah permukaan air. Media biofilter yang digunakan secara umum dapat berupa material organik atau bahan material anorganik. Untuk media biofilter dari bahan organik, misalnya dalam bentuk tali, bentuk jaring, bentuk butiran tak teratur (random packing), bentuk papan (plate), bentuk sarang tawon dan lain-lain. Sedangkan untuk media dari bahan anorganik, misalnya batu pecah (split), kerikil, batu marmer, batu tembikar, batu bara (kokas) dan lainnya.

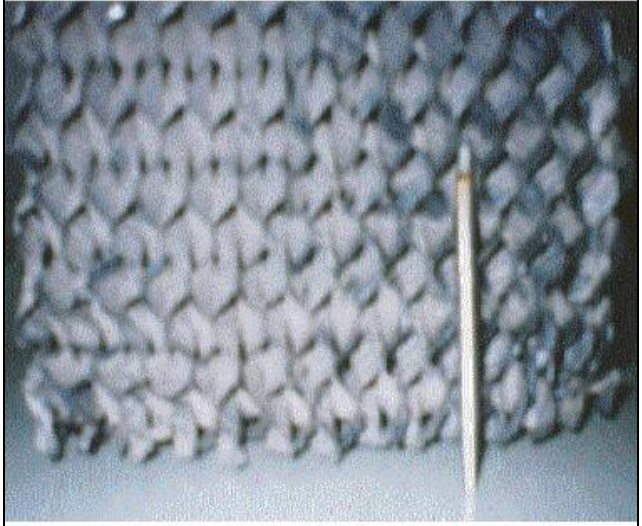

(a)

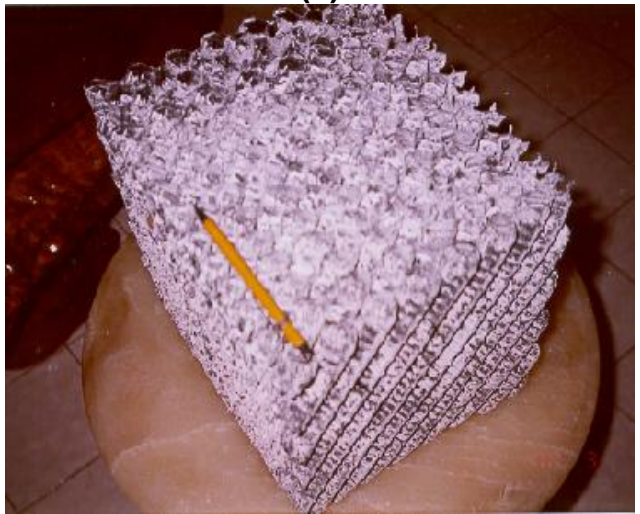

(b)

Gambar 8. (A) Media Biofilter Yang Belum Ditumbuhi Bakteri Atau Lapisan Biofilm Dan (B) Biofilter Yang Telah Dilapisi Oleh Biofilm

Di dalam proses pengolahan air limbah dengan sistem biofilter tercelup aerobik, sistem suplai udara dapat dilakukan beberapa cara, antara lain: aerasi samping, aerasi tengah (pusat), aerasi merata seluruh permukaan, aerasi eksternal, aerasi dengan "air lift pump", dan aerasi dengan sistem mekanik. Masing-masing cara mempunyai keuntungan dan kekurangan. Sistem aerasi juga tergantung dari jenis media maupun efisiensi yang diharapkan. Penyerapan oksigen dapat terjadi terutama karena aliran sirkulasi atau aliran putar kecuali pada sistem aerasi merata seluruh permukaan media.

Di dalam proses biofilter dengan sistem aerasi merata, lapisan mikroorganisme yang melekat pada permukaan media mudah terlepas, sehingga seringkali proses menjadi tidak stabil. Tetapi di dalam sistem aerasi melalui aliran putar, kemampuan penyerapan oksigen hampir sama dengan sistem aerasi dengan menggunakan difuser, oleh karena itu untuk penambahan jumlah beban yang besar sulit dilakukan. Berdasarkan hal tersebut di atas, belakangan ini penggunaan sistem aerasi merata banyak dilakukan karena mempunyai kemampuan penyerapan oksigen yang besar. 
Jika kemampuan penyerapan oksigen besar, maka dapat digunakan untuk mengolah air limbah dengan beban organik (organic loading) yang besar pula. Oleh karena itu diperlukan juga media biofilter yang dapat melekatkan mikroorganisme dalam jumlah yang besar. Biasanya untuk media biofilter dari bahan anorganik, semakin kecil diameternya luas permukaannya semakin besar, sehingga jumlah mikroorganisme yang dapat dibiakkan juga menjadi besar pula. Jika sistem aliran dilakukan dari atas ke bawah (down flow), maka sedikit banyak terjadi efek filtrasi, sehingga terjadi proses penumpukan lumpur organik pada bagian atas media yang dapat mengakibatkan penyumbatan. Oleh karena itu perlu proses pencucian secukupnya. Jika terjadi penyumbatan maka dapat terjadi aliran singkat (short pass) dan juga terjadi penurunan jumlah aliran sehingga kapasitas pengolahan dapat menurun secara drastis.

Untuk media biofilter dari bahan organik banyak yang dibuat dengan cara dicetak dari bahan tahan karat dan ringan, misalnya PVC dan lainnya, dengan luas permukaan spesifik yang besar dan volume rongga (porositas) yang besar, sehingga dapat melekatkan mikroorganisme dalam jumlah yang besar dengan resiko kebuntuan yang sangat kecil. Dengan demikian memungkinkan untuk pengolahan air limbah dengan beban konsentrasi yang tinggi serta efisiensi pengolahan yang cukup besar. Salah Satu contoh media biofilter yang banyak digunakan, yakni media dalam bentuk sarang tawon (honeycomb tube) dari bahan PVC. Beberapa contoh perbandingan luas permukaan spesifik dari berbagai media biofilter dapat dilitat pada Tabel 1.

Tabel 1. Perbandingan Luas Permukaan Spesifik Media Biofilter.

\begin{tabular}{|c|l|c|}
\hline No. & \multicolumn{1}{|c|}{ Jenis Media } & $\begin{array}{c}\text { Luas permukaan } \\
\text { spesifik }\left(\mathrm{m}^{2} / \mathrm{m}^{3}\right)\end{array}$ \\
\hline 1 & $\begin{array}{l}\text { Trickling Filter } \\
\text { dengan batu } \\
\text { pecah }\end{array}$ & $100-200$ \\
\hline 2 & $\begin{array}{l}\text { Modul Sarang } \\
\text { Tawon (honey } \\
\text { comb modul) }\end{array}$ & $150-240$ \\
\hline 3 & Tipe Jaring & 50 \\
\hline 4 & RBC & $80-150$ \\
\hline
\end{tabular}

\section{(5). Aplikasi Biofilter Tercelup Menggunakan Media Batu Pecah}

Reaktor percobaan seperti pada Gambar 9. Berdasarkan pengamatan secara kenampakan fisik pada awal proses, yakni pengamatan setelah dua hari operasi, proses pengolahan belum berjalan secara baik. Hal ini karena mikroorganisme yang ada di dalam reaktor biofilter belum tumbuh secara optimal. Proses yang terjadi terlihat masih merupakan proses pengendapan dan penyaringan secara fisik. Di dalam bak aerasi buih yang terjadi cukup banyak. Hal ini menunjukkan bahwa penguraian senyawa deterjen belum berjalan secara baik. Air yang keluar dari reaktor sudah relatif bersih dibandingkan dengan air limbah yang masuk.

Setelah proses berjalan sekitar satu minggu, mikroorganisme sudah mulai tumbuh atau berkembang biak di permukaan media kerikil. Pada permukaan media kontaktor (batu pecah atau kerikil) yang ada di dalam zona anaerob maupun zona aerob, telah diselimuti oleh lapisan mikroorganisme. Dengan tumbuhnya lapisan mikroorganisme tersebut, maka selain proses penyaringan padatan tersuspensi (SS) secara fisik, penguraian senyawa pencemar yang ada di dalam air limbah secara biologis juga sudah mulai berjalan. Hal ini secara fisik dapat dilihat dari air limpasan yang keluar dari zona anaerob sudah cukup jernih, dan buih atau busa yang terjadi di zona aerob (bak aerasi) sudah berkurang. Sedangkan air olahan yang keluar secara fisik sudah jernih.

Dari hasil analisa kimia contoh air limbah yang masuk dan air hasil olahan, dengan waktu tinggal 3 hari, setelah satu minggu operasi konsentrasi COD air limbah yang masuk 807,7 $\mathrm{mg} / \mathrm{l}$ turun menjadi 206,73 mg/l dengan efisiensi penghilangan $74,4 \%$. Pada saat operasi berjalan dua minggu konsentrasi COD air limbah 1500 $\mathrm{mg} / \mathrm{l}$ turun menjadi $92,16 \mathrm{mg} / \mathrm{l}$ dengan efisiensi penghilangan $93,9 \%$. Setelah dua minggu operasi, waktu tinggal air limbah di dalam reaktor diubah menjadi dua hari, dan pada minggu ke tiga konsentrasi COD di dalam air limbah yang masuk $1257 \mathrm{mg} / \mathrm{l}$, dan konsentrasi COD di dalam air olahan turun menjadi $140,59 \mathrm{mg} / \mathrm{l}$, dengan efisiensi penghilangan COD $88,8 \%$. Pada minggu ke empat setelah operasi berjalan konsentrasi COD air limbah yang masuk 1313,8 $\mathrm{mg} / \mathrm{l}$ dan konsentrasi COD air olahan $100 \mathrm{mg} / \mathrm{l}$, efisiensi penghilangan COD 92,8\%. 


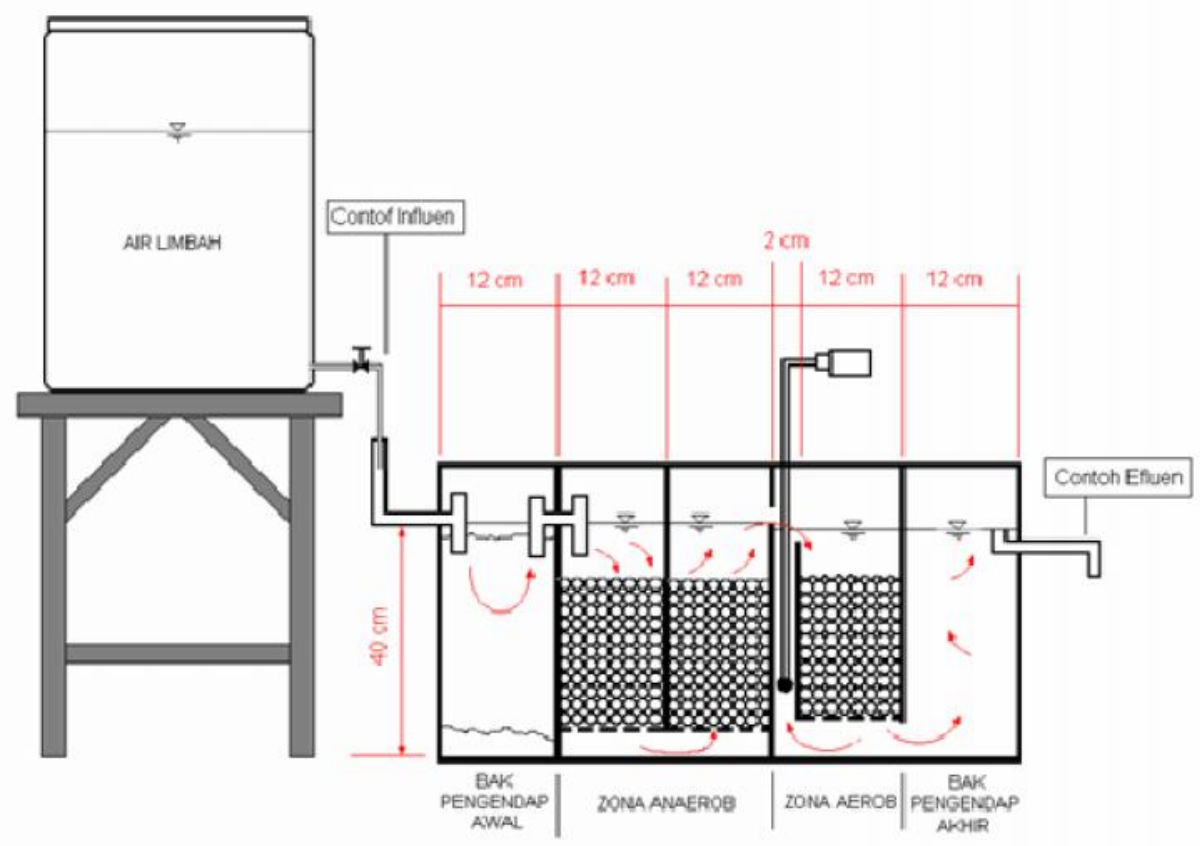

Gambar 9. Penampang Reaktor Biologis Biofilter Tercelup "Anaerob-Aerob"Untuk Pengolahan Air Limbah Yang Digunakan Untuk Percobaan

Setelah operasi pada minggu ke empat waktu tinggal air limbah di dalam reaktor diubah menjadai satu hari. Setelah operasi berjalan pada minggu ke lima konsentrasi COD air limbah masuk $728,97 \mathrm{mg} / \mathrm{l}$ dan konsentrasi COD air olahan $52,17 \mathrm{mg} / \mathrm{l}$, efisiensi penghilangan COD $92,8 \%$. Pada minggu ke enam setelah operasi berjalan, konsentrasi COD air limbah masuk 447 $\mathrm{mg} / \mathrm{l}$ dan konsentrasi COD air olahan 47,06 mg/l, efisiensi penghilangan COD 89,5\%. Dari hasil tersebut dapat terlihat bahwa dengan kombinasi proses biofilter anaerob-aerob, dengan total waktu tinggal satu hari efisiensi penghilangan senyawa organik (COD) masih cukup besar dan relatif stabil. Hasil analisa konsentrasi COD di dalam air limbah masuk dan air olahan serta efisiensi penghilangan COD selengkapnya dapat dilihat pada Gambar 10.

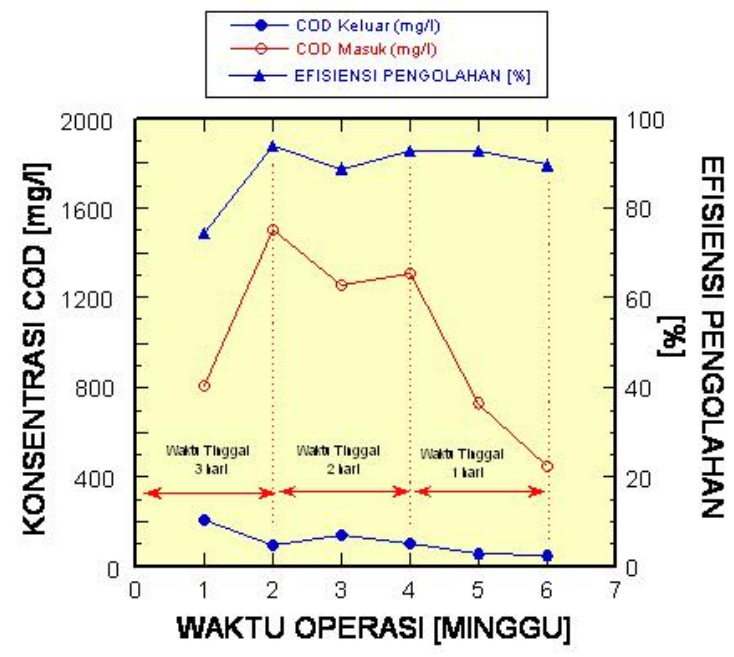

Gambar 10. Konsentrasi COD Sebelum Dan Sesudah Pengolahan Serta Efisiensi Penghilangan

Analisa konsentrasi BOD di dalam air limbah dan air hasil olahan mulai dilakukan setelah operasi pada minggu ke dua, ke tiga, ke empat, ke lima dan setelah minggu ke enam. Hasil analisa konsentrasi BOD di dalam air limbah sebelum dan sesudah pengolahan serta efisiensi penghilangan BOD dapat dilihat pada Gambar 11

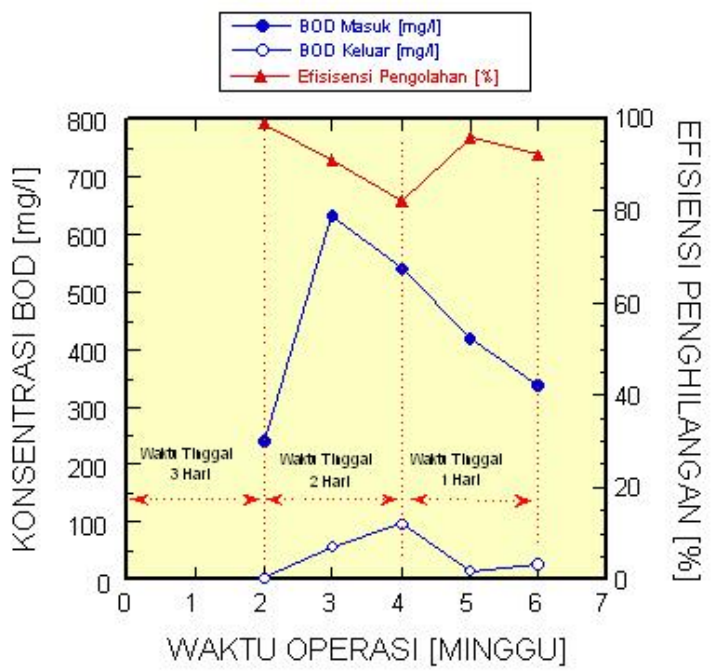

Gambar 11. Konsentrasi BOD Sebelum Dan Sesudah Pengolahan Serta Efisiensi Penghilangan

Dari hasil analisa tersebut dapat dilihat bahwa konsentrasi BOD di dalam air limbah yang masuk berfluktuasi antara $240 \mathrm{mg} / \mathrm{l}$ sampai dengan 630 
$\mathrm{mg} / \mathrm{l}$, sedangkan konsentrasi BOD di dalam air olahan kerkisar antara $2,5 \mathrm{mg} / \mathrm{l}$ sampai dengan $96,5 \mathrm{mg} / \mathrm{l}$, dengan efisiensi penghilangan BOD antara $82,2 \%$ sampai dengan $98,96 \%$. Dari hasil tersebut dapat terlihat juga bahwa dengan waktu tinggal satu hari efisiensi penghilangan BOD cukup tinggi yakni antara 92\% dan $96 \%$.

\section{(6). Aplikasi Biofilter Untuk Pengolahan Air Limbah Domestik}

Air limbah rumah tangga yang akan diolah dikumpulkan dari beberapa rumah dengan cara mengalirkannya melalui pipa PVC. Jenis air limbah yang diolah yakni seluruh air limbah rumah tangga yang berasal dari air bekas cucian, buangan dapur, buangan kamar mandi dan buangan (limbah) tinta. Air limbah dialirkan ke alat pengolahan melalui lubang pemasukan (inlet) masuk ke ruang (bak) pengendapan awal. Selanjutnya air limpasan dari bak pengendapan awal dialirkan ke zona anaerob. Zona anaerob tersebut terdiri dari dua ruangan yang diisi dengan media dari bahan plastik sarang tawon untuk pembiakan mikroba. Pada zona anaerob pertama air limbah mengalir dengan arah aliran dari atas ke bawah, sedangkan pada zona anaerob ke dua air limbah mengalir dengan arah aliran dari bawah ke atas.

Selanjutnya air limpasan dari zona anaerob ke dua mengalir ke zona aerob melalui lubang (weir). Di dalam zona aerob tersebut air limbah dialirkan ke unggun media plastik sarang tawon dengan arah aliran dari bawah ke atas, sambil dihembus dengan udara. Air limbah dari zona aerob masuk ke bak pengendapan akhir melalui saluran yang ada di bagian bawah. Air limbah yang ada di dalam bak pengendapan akhir tersebut disirkulasikan ke zona anaerob pertama, sedangkan air limpasan dari bak pengendapan akhir tersebut merupakan air hasil olahan dan keluar melalui lubang pengeluaran, selanjutnya masuk ke bak kontaktor khlor. Selanjutnya air limpasan dari bak kontaktor dibuang ke saluran umum. Setelah proses berjalan selama dua sampai empat minggu pada permukaan media sarang tawon akan tumbuh lapisan mikro-organisme, yang akan menguraikan senyawa pencemar yang ada dalam air limbah.

Prototipe alat ini dibuat dari bahan fiber glass (FRP) dan dibuat dalam bentuk yang kompak dan langsung dapat dipasang dengan ukuran panjang $310 \mathrm{~cm}$, lebar $100 \mathrm{~cm}$ dan tinggi $200 \mathrm{~cm}$. Ruangan di dalam alat tersebut dibagi menjadi beberapa zona, yakni rungan pengendapan awal, zona biofilter anaerob, zona biofilter aerob dan ruangan pengendapan akhir. Media yang digunakan untuk biofilter adalah media plastik sarang tawon. Air limbah yang ada di dalam rungan pengendapan akhir sebagian disirkulasi ke zona aerob dengan menggunakan pompa sirkulasi. Prototipe alat tersebut dirancang untuk dapat mengolah air limbah sebesar 6 $\mathrm{m} 3 /$ hari, atau untuk melayani sekitar 40-50 orang. Desain alat dapat disesuaikan dengan kapasitas air limbah yang akan diolah atau disesuaikan dengan luas lahan yang tersedia. Untuk kapasitas pengolahan yang lebih besar atau lebih kecil dapat dirancang sesuai dengan kebutuhan. Gambar rancangan sistem pengolahan air limbah dengan kombinasi proses biofilter anaerob-aerob tersebut ditunjukkan seperti pada gambar 12 .

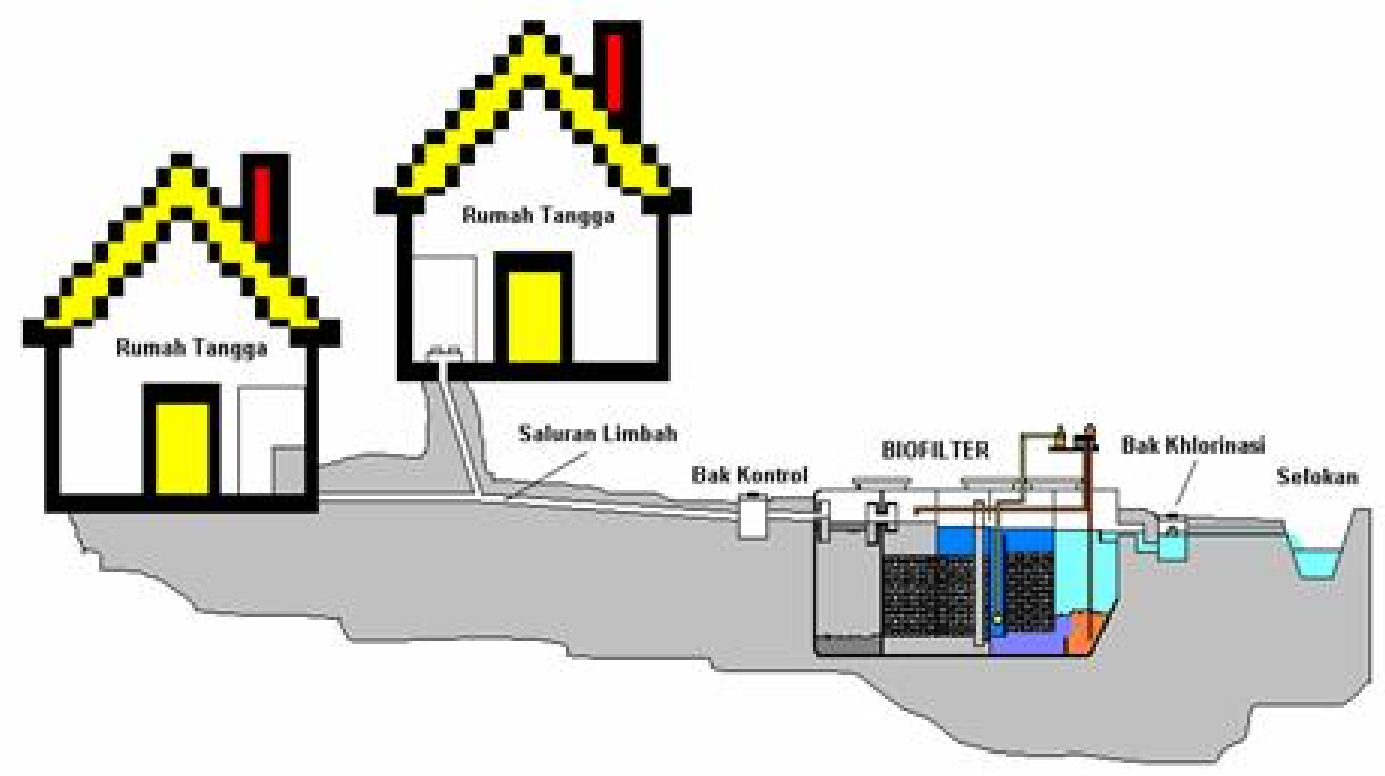

Gambar 12. Bagan Aliran Air Limbah Dan Proses Pengolahan Yang Digunakan Untuk Percobaan 
Dari hasil uji coba prototipe alat pengolah air limbah rumah tangga "Kombinasi Biofilter Anaerob-Aerob" tersebut di atas dapat disimpulkan bahwa : dengan waktu tinggal antara 1- 3 hari, dan proses sirkulasi dengan rasio resirkulasi hidrolik, $\mathrm{HRR}=1$ didapatkan efisiensi pengolahan yang cukup tinggi yakni BOD 84,7 - $91 \%$, COD 79,6 - 95,3\%, SS 94,1 - $95 \%$, Ammonia $\left(\mathrm{NH}_{4}-\mathrm{N}\right)$ 89,3 - 89,8\%, Deterjen (MBAS) 83 - $87 \%$ dan Phospat $\left(\mathrm{PO}_{4}\right)$ 44,4-47,3\%. Efisiensi pengolahan khususnya penghilangan senyawa organik (BOD, COD) dan SS cukup stabil meskipun debit dan konsentrasi pencemar dalam air limbah sangat berfluktuasi. Unit alat pengolah air limbah rumah tangga dengan sistem kombinasi biofilter anaerob-aerob ini dapat dibuat dengan skala kecil ataupun skala besar sesuai dengan kebutuhan. Untuk pengolahan air limbah rumah tangga dengan kapasitas 40 orang (5-6 $\mathrm{M}^{3}$ per hari) memerlukan energi listrik sekitar 65 watt.

\section{(7). Aplikasi Biofilter Untuk Pengolahan Air Limbah Di Rumah Sakit}

Prototipe alat ini secara garis besar terdiri dari bak pengendapan/pengurai anaerob dan unit pengolahan lanjut dengan sistem biofilter anaerob-aerob. Bak pengurai anaerob dibuat dari bahan beton cor atau dari bahan fiber glas (FRP), disesuaikan dengan kondisi yang ada. Ukuran bak pengurai anaerob yakni panjang $200 \mathrm{~cm}$, lebar $200 \mathrm{~cm}$, dan kedalaman efektif sekitar $220 \mathrm{~cm}$, dengan waktu tinggal sekitar 8 jam. Unit pengolahan lanjut dibuat dari bahan fiber glas (FRP) dan dibuat dalam bentuk yang kompak dan langsung dapat dipasang dengan ukuran panjang $310 \mathrm{~cm}$, lebar $100 \mathrm{~cm}$ dan tinggi $190 \mathrm{~cm}$. Ruangan di dalam alat tersebut dibagi menjadi beberapa zona yakni rungan pengendapan awal, zona biofilter anaerob, zona biofilter aerob dan ruangan pengendapan akhir. Media yang digunakan untuk biofilter adalah batu apung atau batu pecah dengan ukuran 1-2 cm, atau dari bahan lain misalnya zeolit, batubara (anthrasit), palstik dan lainnya. Selain itu, air limbah yang ada di dalam ruangan pengendapan akhir sebagian disirkulasi ke zona aerob dengan menggunakan pompa sirkulasi.

Prototipe alat ini dirancang untuk dapat mengolah air limbah sebesar $20 \mathrm{~m}^{3} /$ hari, yang dapat melayani rumah sakit dengan 50 tempat tidur (bed). Percontohan alat pengolah air limbah rumah sakit dibanguin di lokasi Rumah Sakit "Makna", Ciledug, Tangerang. Air yang diolah adalah seluruh limbah cair yang dihasilkan oleh kegiatan rumah sakit, yakni baik yang berasal dari limbah domistik maupun limbah yang berasal dari limbah klinis. Air hasil olahan dapat langsung dibuang ke saluran umum. Diagram proses pengolahan air limbah rumah sakit dengan proses biofilter anaerob-aerob menggunakan media sarang tawon (Gambar 13).

Berdasarkan pengamatan secara fisik (dengan mata), pada awal proses yakni pengamatan setelah dua hari operasi, proses pengolahan belum berjalan secara baik. Hal ini karena mikroorganisme yang ada di dalam reaktor belum tumbuh secara optimal, walupun demikian air yang keluar dari reaktor sudah relatif bersih dibandingkan dengan air limbah yang masuk. Setelah proses berjalan berjalan sekitar dua minggu, mikroorganisme sudah mulai tumbuh atau berkembang biak di dalam reaktor. Di dalam bak pengendapan awal sudah mulai terlihat lapisan mikro organisme yang menempel pada permukaan media. Mikro orgnisme tersebut sangat membantu menguraikan senyawa organik yang ada di dalam air limbah.

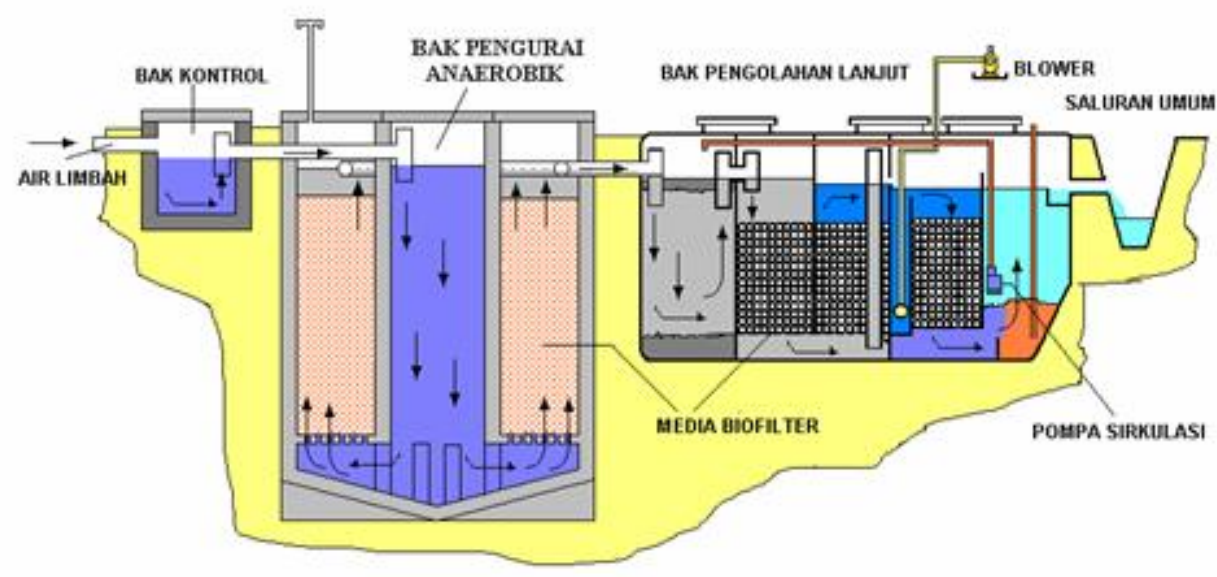

Gambar 13. Diagram Proses Pengolahan Air Limbah Dengan Proses Biofilter Anaerob-Aerob 
Dengan berkembang-biaknya mikro organisme atau bakteri pada permukaan media maka proses penguraian senyawa pencemar yang ada di dalam air limbah menjadi lebih efektif. Selain itu, setelah proses berjalan beberapa satu bulan pada permukaan media kontaktor (media plastik sarang tawon dan batu pecah) yang ada di dalam zona anaerob maupun zona aerob, telah diselimuti oleh lapisan mikroorganisme. Dengan tumbuhnya lapisan mikroorganisme tersebut maka proses penyaringan padatan tersuspensi (SS) maupun penguraian senyawa pencemar yang ada di dalam air limbah menjadai lebih baik.

Hal ini secara fisik dapat dilihat dari air limpasan yang keluar dari zona anaerob sudah cukup jernih, dan buih atau busa yang terjadi di zona aerob (bak aerasi) sudah sangat berkurang. Sedangkan air olahan yang keluar secara fisik sudah sangat jernih. Lapisan mikroorganisme atau biofilm yang telah tumbuh pada permukaan media dapat dilihat pada Gambar 14 dan air hasil olahannya.

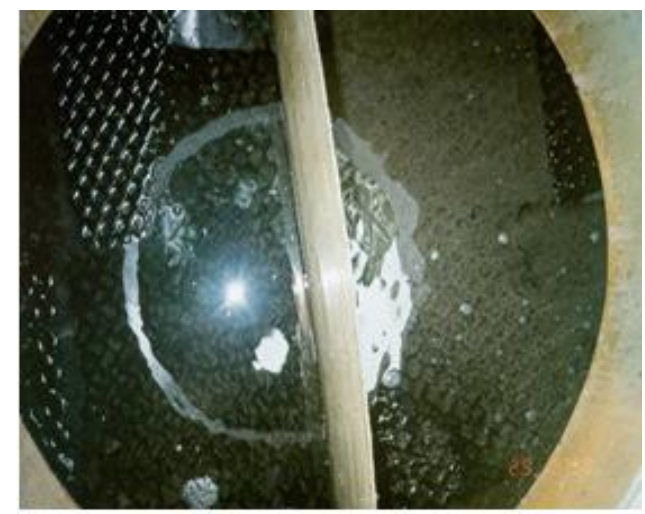

(a)

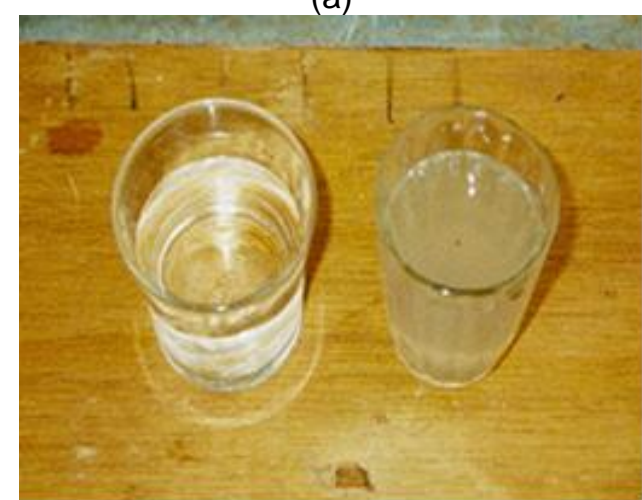

(b)

Gambar 14. Lapisan Mikroorganisme Yang Telah Tumbuh Dan Menempel Pada Permukaan Media Biofilter (A) dan Kenampakan Air Setelah Diolah (Kiri ) dan Sebelum Diolah Kanan (B).

Hasil analisa kualitas air limbah sebelum dan sesudah pengolahan setelah proses berjalan selama empat minggu ditunjukkan pada Tabel 2.
Hasil uji coba pengolahan air limbah rumah sakit dengan proses "Kombinasi Biofilter AnaerobAerob" tersebut dapat menurunkan kandungan zat organik (BOD) dari $419 \mathrm{mg} / \mathrm{l}$ turun menjadi $16,6 \mathrm{mg} / \mathrm{l}$. Konsentrasi COD di dalam air limbah dapat diturunkan dari $729 \mathrm{mg} / \mathrm{l}$ menjadi $52 \mathrm{mg} / \mathrm{l}$. Konsentrasi padatan tersuspensi (SS) dapat diturunkan dari $825 \mathrm{mg} / \mathrm{l}$ menjadi $10 \mathrm{mg} / \mathrm{l}$, sehingga air olahan yang dihasilkan sudah sangat jernih. Konsentrasi deterjen (MBAS) di dalam air limbah dapat diturunkan dari $12 \mathrm{mg} / \mathrm{l}$ menjadi $2,5 \mathrm{mg} / \mathrm{l}$. Untuk proses pengolahan air limbah dengan kapasitas $10-15 \mathrm{M}^{3}$ per hari hanya membutuhkan listrik 65 watt, yakni untuk blower udara 40 watt dan pompa sirkulasi 25 watt.

Tabel 2 : Hasil Analisa Air Limbahrumah Sakit Sebelum Dan Sesudah Pengolahan

\begin{tabular}{|c|l|c|c|}
\hline No & $\begin{array}{c}\text { PARA- } \\
\text { METER }\end{array}$ & $\begin{array}{c}\text { KONSENTRASI } \\
\text { AIR LIMBAH } \\
\text { (mg/l) }\end{array}$ & $\begin{array}{c}\text { KONSENTRASI } \\
\text { AIR OLAHAN } \\
\text { (mg/l) }\end{array}$ \\
\hline 1 & BOD & 419 & 16,5 \\
\hline 2 & COD & 729 & 52 \\
\hline 3 & TSS & 825 & 10 \\
\hline 4 & $\mathrm{NH}_{4}-\mathrm{N}$ & 33,68 & 8 \\
\hline 5 & $\mathrm{MBAS}$ & 12 & 2,6 \\
\hline 6 & $\mathrm{pH}$ & 7,3 & 7,9 \\
\hline
\end{tabular}

Setelah operasi berjalan 4 minggu

\section{(8). Aplikasi Biofilter Untuk Pengolahan Air Limbah Industri Tahu Dan Tempe}

Salah satu cara untuk mengatasi masalah air limbah industri tahu-tempe tersebut adalah dengan kombinasi proses pengolahan biologis anaerob dan aerob. Secara umum proses pengolahannya dibagi menjadi dua tahap yakni pertama proses penguraian anaerob (Anaerobic digesting), dan yang ke dua proses pengolahan sistem biofilter aerob. Secara garis besar proses pengolahan air limbah industri tahu dan tempe ditunjukkan seperti pada Gambar 15 dan 16

Unit IPAL terdiri dari bak berbentuk segi empat yang dibagi menjadi 8 ruangan. Air limbah yang berasal dari limbah proses pembuatan tahu-tempe maupun air limbah rumah tangga dikumpulkan melalui saluran terbuka, selanjutnya dialirkan ke bak saringan kasar untuk memisahkan sampah atau kotoran padat lainnya. Setelah itu air limbah masuk ke bak pengendapan awal (bak 1). Air limpasan dari bak pengendap awal masuk ke zona anaerob yang terdiri dari bak 2, bak 3 dan bak 4 dan kak 5 . Bak 2 sampai bak 4 merupakan bak pengurai anaerob tanpa media penyangga, sedangkan bak 5 merupakan bak pengurai dengan 
menggunakan media penyangga dari bahan plastik tipe sarang tawon. Dari bak 5 air limbah masuk ke zona aerob yang terdiri dari ruang aerasi (bak 6) dan ruang biofilter aerob (bak 7).

Di dalam bak aerasi (bak 6) air limbah dihembus dengan udara menggunakan blower udara, selanjutnya masuk ke bak kontaktor aerob (biofilter aerob). Di dalam bak kontaktor aerob ini diisi dengan media dari bahan plastik (PVC) tipe sarang tawon sehingga mikro organisme yang ada akan tumbuh dan menempel pada permukaan media serta menguraikan zat organik yang ada dalam air limbah. Dengan demikian air limbah akan kontak dengan mikroorgainisme yang tersuspensi dalam air maupun yang menempel pada permukaan media yang mana hal tersebut dapat meningkatkan efisiensi penguraian zat organik, deterjen serta mempercepat proses nitrifikasi, sehingga efisiensi penghilangan ammonia menjadi lebih besar. Dari bak aerasi, air dialirkan ke bak pengendap akhir. Di dalam bak ini lumpur aktif yang mengandung massa mikroorganisme diendapkan dan dipompa kembali ke bagian bak aerasi dengan pompa sirkulasi lumpur. Sedangkan air limpasan (over flow) dialirkan ke bak stabilisasi, selanjutnya dibuang ke sungai atau saluran umum.

Hasil pengujian pada limbah tahu dan tempe dapat dilihat pada Gambar 17, penurunan BOD dapat mencapai $85-90 \%$ dan pemakaian media biofilter meningkatkan efisiensi

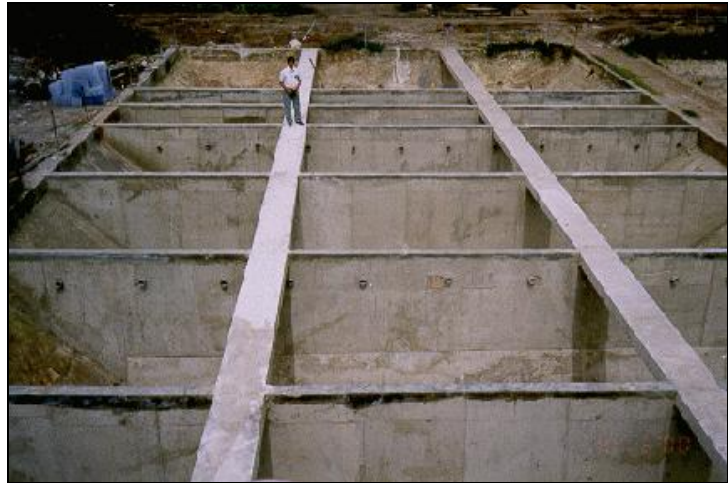

(a)

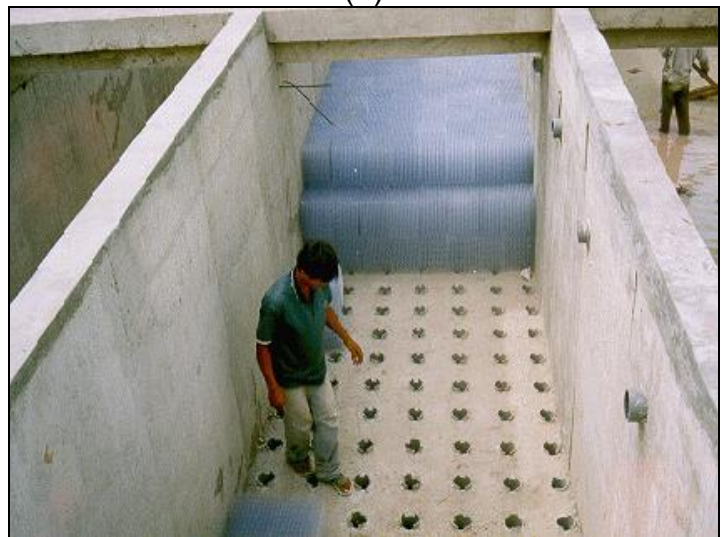

(b)

Gambar 16. Reaktor Kombinasi Anaerob-Aerob Dengan Biofilter Dilihat Dari Atas (A) dan Pemasangan Media Biofilter dan Bagian Dasar Media Biofilter Yang Berpori, Sistem Aliran Up Flow (B). pengolahan limbah.

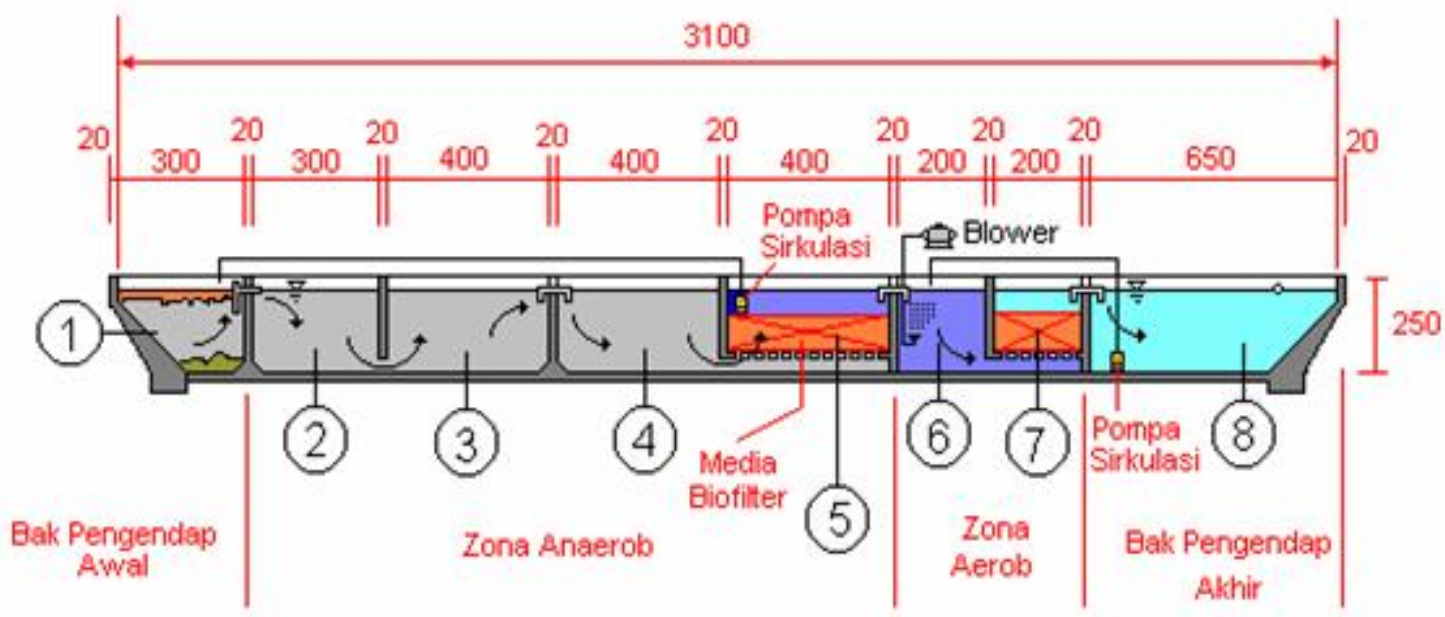

Gambar 15. Diagram Proses Pengolahan Air Limbah Industri Tahu dan Tempe Dengan Sistem Kombinasi Biofilter "Anareb-Aerob" 


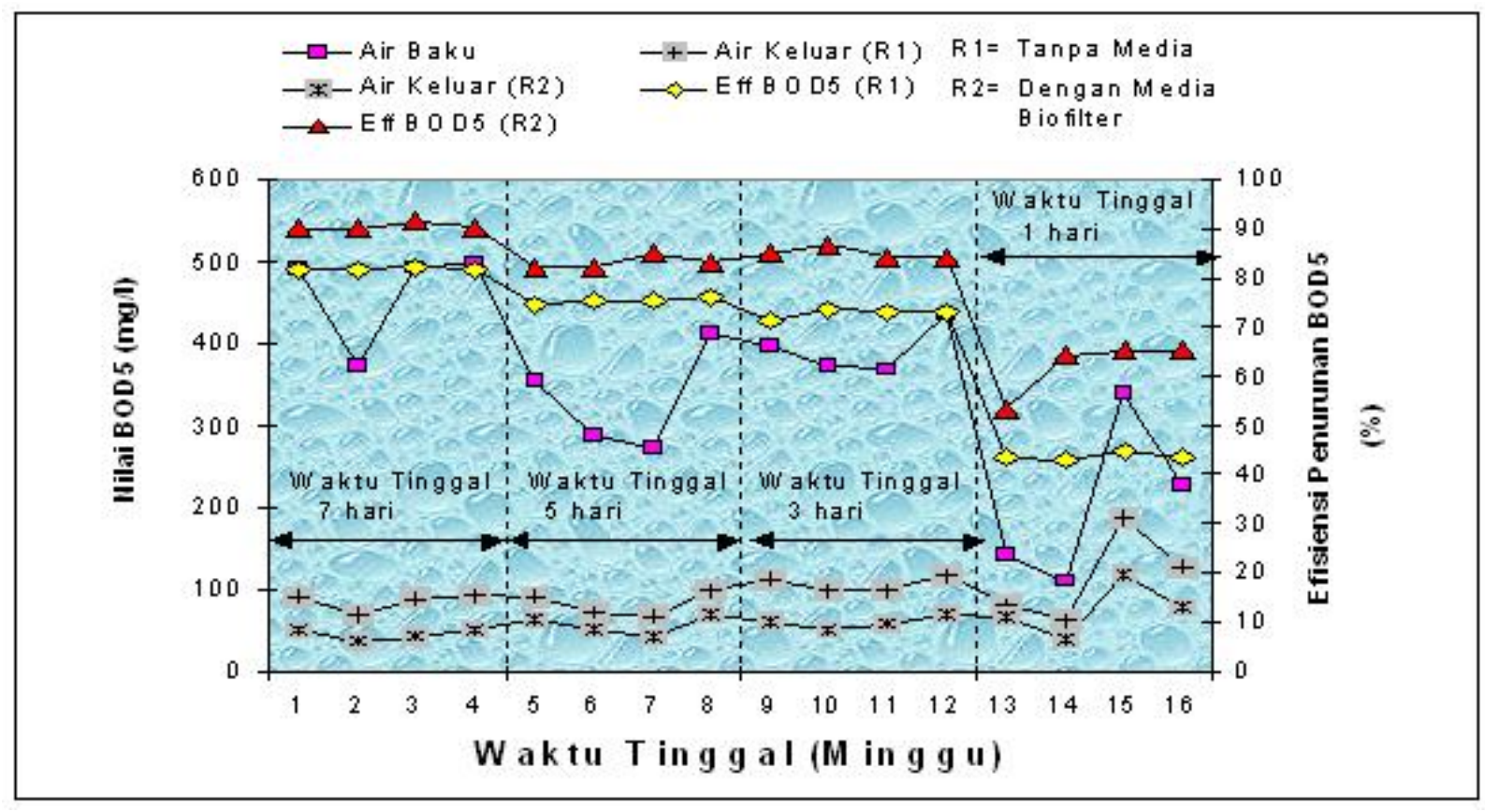

Gambar 17. Perubahan Nilai BOD 5 Pada Reaktor Dengan Media Dan Tanpa Media Biofilter Dalam Waktu Tinggal 7 Sampai 1 Hari

\section{PENUTUP}

1. Prinsip $3 \mathrm{R}$ (Reduce, Reuse, dan Recycle) merupakan prinsip yang sudah diakui keberhasilannya oleh negara-negara maju dalam mengelola limbahnya, prinsip tersebut dalam aplikasinya di Indonesia masih bersifat wacana. Dalam menerapkan prinsip 3R dalam sistem pengelolaan sampah, diperlukan dukungan teknologi yang memadai. Dukungan tersebut sangat diperlukan dalam upaya mencari metoda dan cara yang sesuai dengan kondisi negara kita.

2. Dengan komposisi mayoritas (70-80\%) sampah dari perkotaan terdiri dari bahan organik yang dapat terurai secara alamiah dan $20-30 \%$ bahan non organik, maka proses komposting merupakan salah satu proses alternatif yang paling murah dengan hasil sampingan yang dapat dimanfaatkan kembali sebagai pupuk organik.

3. Limbah cair yang terbuang keperairan alam terdiri sebagian besar $(77-80 \%)$ dari limbah cair domestik, oleh karena itu diprioritas dalam penanganannya. Teknologi pengolahannya banyak macam dan ragamnya, namun demikian dalam pemilkihan teknologi biaya investasi, operasi dan pemeliharaan menjadi pertimbangan utama, selain hasil air olahan yang ingin dicapai.

4. Pencemaran yang terjadi di laut atau teluk atau pelabuhan tidak terlepas dari pencemaran yang terjadi di sungai-sungai yang bermuara ke laut, oleh karena itu penanganan pencemaran di laut tidak terlepas dari penanganan pencemaran air dan penanganan sampah yang ada di darat.

\section{DAFTAR PUSTAKA}

1. ----, " Gesuidou Shissetsu Sekkei Shisin to Kaisetsu “, Nihon Gesuidou Kyoukai, 1984.

2. Abel. P.D. 1989. "Water Pollution Biology", Ellis Horwood Limited, Chichester, West Sussex, England.

3. APHA (American Public Healt Association) 1985. "Standard Methods for the Examination of Water and Waste Water". Washington, D.C.1462 p.

4. FAIR, GORDON MASKEW et.al., " Eements Of Water Supply And Waste Water Disposal", John Willey And Sons Inc., 1971.

5. Gabriel Bitton. $1994 . \quad$ "Wastewater Microbiology", A John Wiley \& Sons, INC., New York.

6. GOUDA T., " Suisitsu Kougaku - Ouyouben", Maruzen kabushiki Kaisha, Tokyo, 1979.

7. HIKAMI, Sumiko., "Shinseki rosohou ni yoru mizu shouri gijutsu (Water Treatment with Submerged Filter)", Kougyou Yousui No.411, $12,1992$.

8. Lay. B.W. dan Hastowo .S. 1994. Analisis Mikroba di Laboratorium, Raja Grafindo Persada, Jakarta.

9. Mahida, U.N 1986. "Pencemaran Air dan Pemanfaatan Industri". Penerbit Rajawali, Jakarta.543 p. 
10. MetCalf dan Eddy. 1991. "Waste Water Engineering", Mc Graw Hill.

11. Nurhasan dan B. Pramudyanto.1987. "Pengolahan Air Buangan Industri Tahu". Yayasan Bina Lestari dan WALHI, Semarang. $37 \mathrm{p}$.

12. Pelczar M.J. Jr. dan Chan. E.C.S. 1986. "Dasar-Dasar Mikrobiologi", UI-Press, Jakarta.

13. Sawyer. C.N. dan McCarty. P.L. 1989. "Chemistry
Engineering", International edition, McGraw-Hill Book, Singapore.

14. Sterrit. R.M. dan Lester.J.N. 1988. "Microbiology for Environmental and Public Health Engineers", E.\&F.N Spon Ltd, London.

15. SUEISHI T., SUMITOMO H., YAMADA K., DAN WADA Y., " Eisei Kougaku " (Sanitary Engineering), Kajima Shuppan Kai, Tokyo, 1987.

16. VIESSMAN W, JR., HAMER M.J., “ Water Supply And Polution Control ", Harper \& Row, New York, 1985. 
Sampah sudah menjadi masalah bagi kota-kota besar dan kecil, karena terkait dengan sanitasi lingkungan dan kesehatan, disamping masalah estetika. Curah hujan yang tinggi mengakibatkan larutnya hasil pembusukan sampah yang tertumpuk baik di TPS maupun TPA terbawa aliran air dan merembes ke dalam air tanah atau mengalir ke perairan umum. Undang-undang Nomor 8 Tahun 2007 tentang persampahan mewajibkan pengelolaan sampah saniter. Saat ini sebagian besar TPA yang ada masih banyak yang belum memenuhi sarat konstruksinya dan masih perlu didukung oleh penerapan program $3 R$ yang solid. Pengolahan limbah cair yang berasal dari leachate (rembesan air) sampah memerlukan pengolahan khusus. Teknologi pengolahannya ada banyak macam dan ragamnya, yang terpenting dapat diaplikasikan dan kualitas air olahannya dapat memenuhi baku mutu.

Solid waste has become a problem for large and small cities, as they relate to environmental sanitation and health, as well as aesthetic issues. High intensity of rainfall influence in a high solubility results of decomposition of waste in both TPS and TPA, brought the flow of water and water soak to soil or water flow to the public drainage. Law Number 8 Year 2007 on waste management require sanitary landfill technology. Currently most of the TPA are still not meet the full construction of sanitary landfill and need to be supported by the application of the $3 R$ (Reduced, Reused, Recycle) program in solidwaste. Processing waste liquid derived from the leachate (seepage water) waste requiring special treatment. There are many type of waste water technology processing, the most important, It can be applied and product water quality meet the standard quality. 